\title{
Organic Carbon Concentrations and Transport in Small Mountain Rivers, Panama
}

\author{
Steven T. Goldsmith ${ }^{1 *}$, W. Berry Lyons ${ }^{2,3}$, Russell S. Harmon ${ }^{4}$, Brendan A. Harmon ${ }^{4}$, \\ Anne E. Carey², Gregg T. McElwee ${ }^{5}$ \\ ${ }^{1}$ Department of Geography and the Environment, Villanova University, Villanova, Pennsylvania 19085, USA \\ ${ }^{2}$ School of Earth Sciences, The Ohio State University, Columbus, Ohio 43210, USA \\ ${ }^{3}$ Byrd Polar Research Center, The Ohio State University, Columbus, OH 43210 \\ ${ }^{4}$ Department of Marine, Earth, and Atmospheric Sciences, North Carolina State University, Raleigh, North Carolina \\ 27695, USA \\ ${ }^{5}$ Department of Earth and Atmospheric Sciences, Cornell University, Ithaca, New York 14853, USA \\ *Corresponding Author at: Department of Geography and the Environment, Villanova University, Villanova, \\ Pennsylvania 19085, USA. Tel: 1-610-519-3589. E-mail: Steven.goldsmith@ villanova.edu.
}

\begin{abstract}
Tropical small mountainous rivers (SMRs) are increasingly recognized for their role in the global export of dissolved organic carbon (DOC) to the oceans. Here we utilize the Isthmus of Panama as an ideal place to provide first-order estimates of DOC yields across a wide assemblage of bedrock lithologies and land cover practices. Samples for dissolved organic carbon (DOC) analysis were collected across Panama along an E-W transect from the central Panama area to the Costa Rican border for 24 mainstem rivers, 3 large tributary rivers, and one headwater stream. Sampling occurred during both the wet and the dry seasons. DOC concentrations during the wet season are higher than during the dry season in all but three of the rivers. Concentrations vary greatly from river to river and from season to season, with values as low as $0.64 \mathrm{mg} \mathrm{l}^{-1}$ to greater than $>25 \mathrm{mg} \mathrm{l}^{-1}$ with the highest concentrations observed for the rivers draining Tertiary marine sedimentary rocks in the Burica and Azuero peninsulas. DOC yields from Panamanian rivers (2.29 to 7.97 tons $/ \mathrm{km}^{2} / \mathrm{y}$ ) are similar to or slightly lower than those determined for other tropical SMR systems. Areas underlain by Tertiary aged sediments exhibited significantly higher mean DOC yields compared to their igneous counterparts, despite maintaining substantially lower aboveground carbon densities, suggesting the important influence of lithology. Finally, regression analyses between DOC yields and select watershed parameters revealed a negative and statistically significant relationship with maximum and mean gradient suggesting lower soil retention times may be linked to lower DOC yields.
\end{abstract}

Key words: Organic carbon, riverine yields, watershed, Panama 


\section{Introduction}

The transport of organic carbon from the terrestrial landscape to the ocean is a major process in the global carbon cycle (Ludwig et al., 1996; Aitkenhead and McDowell, 2000; Raymond and Bauer, 2001; Lyons et al., 2002; Cole et al., 2007). The amount of organic matter transported and buried in marine sediments and terrestrial deposits, compared to the amount of carbon that is recycled in both the terrestrial landscape and the aquatic system, has real importance with regard to global carbon sequestration (Cole et al., 2007). Recently, tropical and subtropical mountainous regions of the world have been shown to play an important role in the transport of particulate organic carbon (POC) and dissolved organic carbon (DOC) to the global ocean (Kao and Liu, 1997; Blair et al., 2003; Gomez et al., 2003; Komada et al., 2004; Carey et al, 2005; Hilton et al., 2012; Lloret et al. 2011, 2013). However, there is still a need to substantiate these suggestions as datasets acquired to date are generally from isolated localities that are of limited spatial extent. This lack of organic carbon flux data is particularly true for the humid tropics which contain as much as $30 \%$ of the world's total soil organic carbon (Batjes, 1996). In addition, these studies often overlook how factors such as lithology, stream geomorphology and ecosystem modification can ultimately modify these rates of DOC export.

This paucity of data has also complicated the search for controls on organic matter export from SMR locales. In fact in many regions of the world fluxes and yields have been determined by extrapolation and by modeling (Ludwig et al., 1996, Lloret et al., 2013). Steep slopes and high rainfall have been attributed to elevated POC yields (Hilton et al., 2012), much of which is transported to the ocean during periodic to aperiodic intense precipitation events (Goldsmith et al., 2008; Hilton et al., 2008; Wohl et al., 2012). However, these same factors have been shown to have a varying relationship with DOC yields (Guyot and Wasson, 1994; Townsend-Small et al., 2005; Lloret et al., 2013) as thin soils prevent the building up of organic material in shallow soils. To discern elevation effects on DOC concentrations in SMRs is often further complicated by the influence of anthropogenic activities associated with higher population densities at lower altitudes (Yang et al., 2013). Furthermore, studies on DOC export from subtropical and tropical SMRs tend to focus on monolithic settings consisting of either uplifted sedimentary/lightly metamorphosed terrains (Kao and Liu, 1997; Carey et al., 2005; Alin et al., 2008) or volcanic islands (Lloret et al. 2011; 2013) with limited inter-basin climate variability. Thus, an understanding of the role of these constraining factors is crucial before extrapolating values to other settings for modeling purposes.

This paper addresses existing knowledge gaps by presenting both wet and dry seasons DOC concentrations for 24 mainstem rivers, 3 tributary rivers, and a headwater stream from central 
and western Panama. In addition, DOC yields have been calculated from watersheds where river discharge measurements exist. DOC yields are subsequently compared to a series of hydrologic, lithologic, geomorphologic, and land cover parameters in a search for controls. These data substantially improve our overall knowledge of carbon yields from tropical watersheds.

\section{The West-Central Panama Study Area}

Panama is located in the humid seasonal tropics and has a tropical climate that is characterized by constant high temperature at sea level and low elevation, distinct wet and dry seasons, and annual rainfall exceeding evapotranspiration across most of the country (Kotteck et al., 2006; Peel et al., 2007). Temperatures are uniformly high across the country, with each month of the year having an average temperature of $18{ }^{\circ} \mathrm{C}$ or higher and seldom exceeding $32{ }^{\circ} \mathrm{C}$, except in the higher parts of the mountain ranges where frosts can occur during winter months.

Rainfall across Panama is strongly seasonal, with pronounced wet and dry seasons, and varies regionally from less than $1.3 \mathrm{~m}$ to nearly $7 \mathrm{~m}$ per year (Rand and Rand, 1982; Cavelier et al., 1996). Because the primary source of moisture to Panama's precipitation comes from the Atlantic Ocean, the Atlantic coastal region receives greater rainfall than the Pacific coastal region on the leeward side of the continental divide. Rain falls throughout the year along the Caribbean coast, so that annual accumulations on the north slopes of the Cordillera Central can range 3000-7000 mm, whereas the Pacific coast of central Panama and the Azuero peninsula have a tropical dry and wet climate with annual rainfall of $<2000 \mathrm{~mm}$. The Cordillera Central creates an elevation barrier and, therefore, a strong climate gradient from north to south across Panama that generates higher precipitation and consequent greater runoff, erosion, and river incision on the Caribbean side of Panama compared to the Pacific side. About $90 \%$ of the annual precipitation falls during the rainy season between May and December. This wet period is followed by a marked dry season from January to April. River discharge correlates well with precipitation. Since wet season storms approach Panama from the north, the Caribbean slope of the Cordillera Central is moist and heavily forested by comparison to the Atlantic side, which has a longer dry season, receives less precipitation, and therefore is comparatively drier and much more developed (Condit at al., 2001). The H- and O- isotopic composition of surface waters in Panama becomes more depleted with distance from the Caribbean coast, documenting progressive rainout as the moisture-rich air masses move southward across the country (Lachniet and Patterson, 2006; Harmon et al., 2009).

The land that today composes Panama formed over the past 140 million years as a consequence of Caribbean, South American, Cocos, and Nazca plate interactions as an island arc 
archipelago developed on Mezozoic oceanic crust of the Caribbean plate and interacted with associated marine sedimentary basins (Molnar and Sykes, 1969). Geologically, Panama consists of a mosaic of bedrock lithologies that range from hydrothermally altered marine oceanic crust, intrusive mafic to intermediate composition, igneous rocks, a broad array of volcanic rock compositions, and uplifted loosely consolidated marine and clastic sedimentary rocks deposited unconformably upon the igneous rocks of the volcanic arcs during Tertiary time in the Bocas del Toro region, the Burica and Azuero peninsulas, and in portions of the Trans-Isthmus, Colon, and East Panama regions (Coates et al., 2004; Wegner et al., 2011). Silicate rocks across Panama comprise a broad range of volcanic and intrusive lithologies. Tholeiitic to low-K calc-alkaline basalts and andesites dominate the extrusive suite, whereas gabbros to granodiroites are the most common intrusive rocks. As a consequence, the solute signature of Panamanian rivers, which is largely acquired in watershed headwater areas (Harmon et al., 2013), is broadly similar in terms of major elements, except where rivers are developed predominantly on rhyolite and granite or on associated Tertiary shallow marine sediments. The Panama land bridge, which presently forms the terrestrial connection between North and South America, formed during the past few million years by tectonic amalgamation and transpressive faulting of these igneous rocks at this active plate margin (Coates and Obando, 1996).

Across the tropics, oxide and clay minerals accumulate as a thick mantle of residual soil develops above active bedrock weathering in the critical zone. The geomorphic situation in Panama is characteristic of the mountainous tropics, where (i) thick, cation-depleted soils are present on ridges and topographic high ground, (ii) soils on mountain slopes are thin and cation depleted, and (iii) lowland soils are highly variable in both thickness and composition. The dominant soil type in much of Panama can be described as broadly saprolitic, although some minor surficial soil deposits derived from marine sediments are important locally. Like saprolitic soils across the humid tropics, these soils generally consist of clay- and silt-size particles that have been depleted of most alkali and alkaline earth cations, leaving a matrix consisting primarily of oxides of iron and aluminum (e.g. Stallard, 1985). Where quartz-bearing lithologies are present, soils will tend toward a sandy texture having a high permeability, whereas soils on mafic and intermediate volcanic terrains where quartz is absent tend to be fine-grained and are characterized by a decreased porosity and low hydraulic conductivity. It is not uncommon to find multiple soil types in close geographic proximity.

Because of its diverse tropical climate, Panama has one of the world's most varied ecosystems and is noted for its species richness (Myers et al., 2000). Forests dominate across mountain and upland areas, with secondary scrub forest, grasslands, and crops present to varying extents across the lowlands areas and coastal plains. Although nearly 40\% of Panama is still 
wooded, deforestation is a continuing threat to the rain-drenched woodlands. Tree cover has been reduced by more than half over the past fifty years and there is concern that this deforestation is causing soil erosion and affecting the river chemical quality. Subsistence farming is practiced widely across the country and secondary forests arise when low-productivity agricultural land and pastures are abandoned.

Almost 500 rivers drain the mountainous areas of Panama, most of which are small mountain rivers that originate as swift highland streams. In general, rivers in Panama are short, having an average length of $106 \mathrm{~km}$, although an average of only $56 \mathrm{~km}$ for rivers flowing north to the Caribbean Sea, with their overall flow direction tending to be oriented perpendicular to the coast. The largest rivers have produced well-developed valleys and in their lower reaches comprise meandering coastal plain rivers and associated deltas. About one-third of Panamanian rivers flow northward into the Caribbean Sea and drain about 30\% Panama's land area. The remaining twothirds, including 22 of the 24 rivers sampled in this study flow southward into the Pacific Ocean, draining the remaining $70 \%$ of the country. The Rio Pequini and Rio Piedras tributary to the Upper Rio Chagres in the Trans-Isthmus region flow into Lago Alajuela, which is a storage reservoir for Panama Canal operations. The hydrology of Panama is driven by the seasonality of precipitation and the character of the landscape upon which rain falls. Local soil character and hydraulic processes control how incident rainfall is apportioned into surface runoff, infiltration, transmission, evapotranspiration, and ground water recharge. The major factors that determine the extent of runoff production in the mountainous landscape of tropical Panama watersheds are their steep slopes, extensive soil macropore networks, and soils with high water retention capacity.

The rivers of central-western Panama sampled in this study (Fig. 1) have watersheds that range in size about $2-1400 \mathrm{~km}^{2}$ and can be divided into six groups (Table 1) on the basis of their local geology, geomorphology, and land cover as described below. The largest rivers samples, i.e. Rio Chiriqui Viejo, Rio Chiriqui, Rio Fonseca, Rio San Juan, Rio Santa Maria and Rio Pacora, run across the southern coastal plain developed on Tertiary sediments, but were sampled in their middle reaches north of the Pan American highway where the river channels were developed on Tertiary igneous bedrock. 


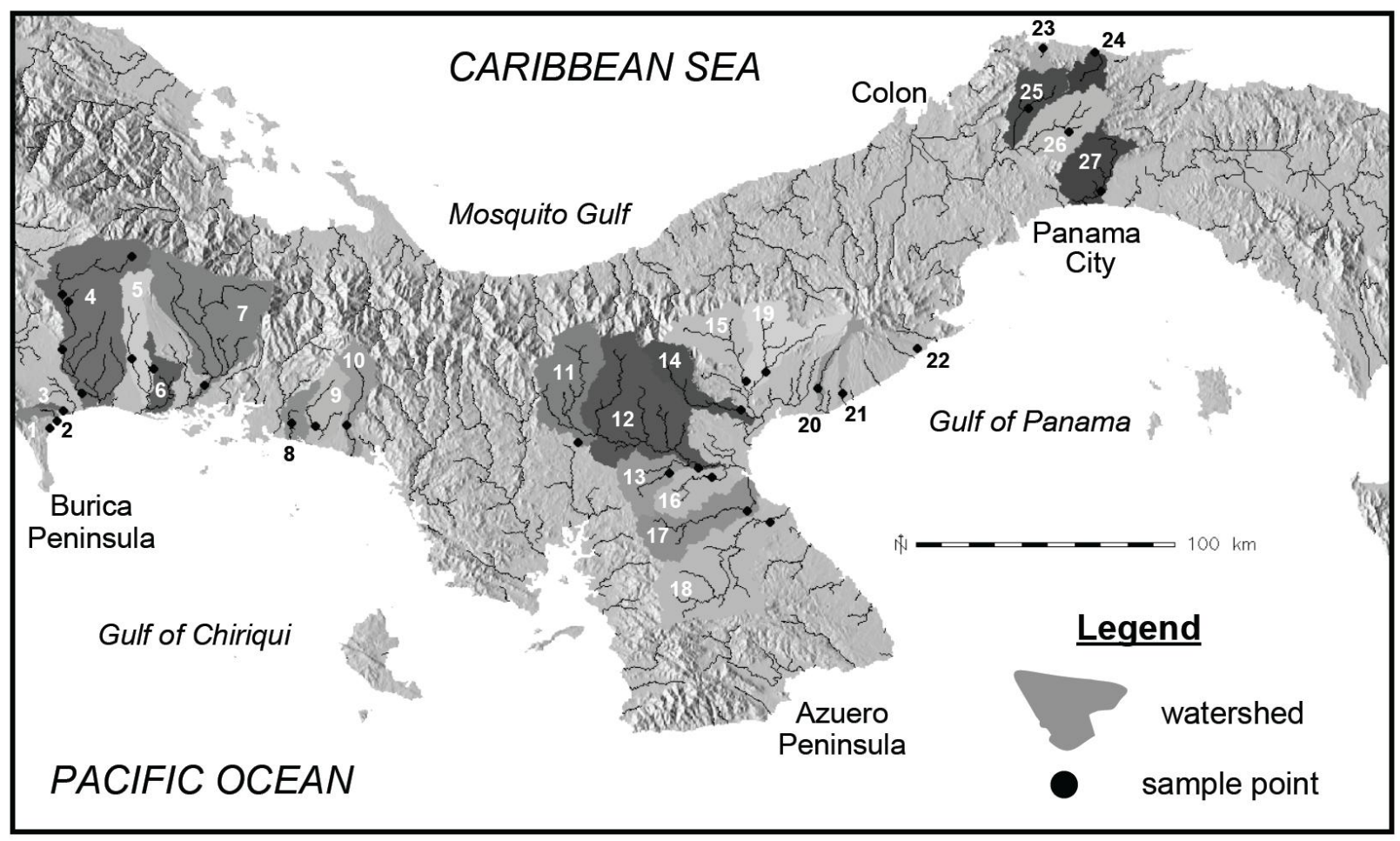

Figure 1. Map of Panama showing rivers and sample collection locations.

Group 1 (Burica Peninsula): Rivers of the Burica Peninsula in far western Panama (Rio Corotu, Rio San Bartolo, and Rio Palo Blanco) drain a surface geology comprising sequences of shallow marine and terrestrial forearc sediments that include limestones, marine siliceous deposits, and detrital volcano-sedimentary units deposited unconformably upon the igneous rocks of the volcanic arcs during Tertiary time (Escalante, 1990). Watersheds in the Burica Peninsula are comparatively small, with areas ranging from just $2-52 \mathrm{~km}^{2}$ and have 22 to to $65 \%$ forest cover.

Group 2 (Chiriqui Region): Rivers of the western Chiriqui province (Rio Chiriqui Viejo and one of its low-order tributary streams, Rio Platanal, and Rio Chico Concépcion) drain the Holocene adakitic basalts and andesites of the Pleistocene-age Volcán Barú (Drummond et al., 1995), whereas those located in the eastern portion of Chiriqui province (Rio Fonseca, Rio San Juan, and Rio San Felix) drain igneous rocks of the 'Older' volcanic arc (Wegner et al., 2011). These watersheds range from $19-606 \mathrm{~km}^{2}$ in size and have 13 to $79 \%$ forest cover.

Group 3 (Veraguas-Cocle Region): Rivers of Veraguas, and western Cocle provinces (Rio Santiago, Rio Grande, Rio Santa Maria, Rio Conaca, Rio Chico, and Rio Cocle) drain igneous rocks of the 'older' and 'younger' volcanic arcs (Wegner et al., 2011), which largely consist of intrusive and extrusive submarine and subaerial volcanic arc suites (Wörner et al., 2005; 2009). 
Table 1: Dissolved organic carbon content during wet and dry season sampling for 27 rivers in Panama

\begin{tabular}{|c|c|c|c|c|c|}
\hline $\begin{array}{l}\text { Map } \\
\text { ID* }\end{array}$ & River & $\begin{array}{l}\text { Sampling } \\
\text { UTM E }\end{array}$ & $\begin{array}{l}\text { Sampling } \\
\text { UTM W }\end{array}$ & $\begin{array}{l}\text { 19-25 Aug } \\
2006 \\
\text { (wet season) } \\
\mathrm{mg} \mathrm{l}^{-1}\end{array}$ & $\begin{array}{l}20 \mathrm{Feb}-1 \\
\text { Mar } 2007 \\
\text { (dry season) } \\
\mathrm{mg} \mathrm{l}^{-1}\end{array}$ \\
\hline & Group 1. Burica Peninsula & & & & \\
\hline 1 & Rio Corotu & 293804 & 913110 & $>25$ & 2.87 \\
\hline 2 & Rio Bartolo & 296301 & 916566 & $>25$ & 1.73 \\
\hline \multirow[t]{2}{*}{3} & Rio Palo Blanco & 298894 & 920017 & 24.55 & 1.67 \\
\hline & Group 2. Chiriqui Region & & & & \\
\hline \multirow[t]{2}{*}{4} & Rio Chiriqui Viejo (n=5) & 298266 & 943179 & 1.52 & 1.21 \\
\hline & Rio Chiriqui Viejo at volcan (headwater reach) & & & 6.19 & ND \\
\hline 5 & Rio Chico Concepcion & 324385 & 939597 & 1.26 & ND \\
\hline 6 & Rio Platanal & 332644 & 935712 & 1.05 & 0.83 \\
\hline 7 & Rio Chiriqui & 351523 & 929671 & 1.55 & 1.01 \\
\hline 8 & Rio Fonseca & 384303 & 915166 & 1.91 & 0.94 \\
\hline 9 & Rio San Juan & 393359 & 913962 & 2.88 & 1.13 \\
\hline \multirow[t]{2}{*}{10} & Rio San Felix & 405028 & 914518 & 0.76 & 0.67 \\
\hline & Group 3. Veraguas-Cocle Region & & & & \\
\hline 11 & Rio Santiago & 419769 & 908175 & 0.87 & 1.96 \\
\hline 12 & Rio Santa Maria & 534705 & 899336 & 3.41 & 1.18 \\
\hline 13 & Rio Conaca & 526169 & 896401 & 4.43 & 2.53 \\
\hline 14 & Rio Chico at Nata (tributary to Rio Grande) & 553005 & 919929 & 1.99 & 1.06 \\
\hline 15 & Rio Grande & 554841 & 931243 & 2.01 & 1.84 \\
\hline \multirow[t]{2}{*}{19} & Rio Cocle del Sur (tributary to Rio Grande) & 562156 & 934710 & 2.97 & 1.41 \\
\hline & Group 4. Azuero Peninsula & & & & \\
\hline 16 & Rio Escota & 541829 & 894670 & 8.85 & 4.15 \\
\hline 17 & Rio Parita & 555561 & 882141 & 9.21 & 2.29 \\
\hline \multirow[t]{2}{*}{18} & Rio La Villa & 563756 & 877880 & 6.46 & 1.29 \\
\hline & Group 5. El Valle Region & & & & \\
\hline 20 & Rio Anton & 581615 & 928571 & 1.92 & 1.08 \\
\hline 21 & Rio Hato & 591099 & 926735 & 1.59 & 1.15 \\
\hline \multirow[t]{2}{*}{22} & Rio Las Lajas & 619042 & 943994 & 4.65 & 2.82 \\
\hline & Group 6.Trans-Panama Region & & & & \\
\hline 23 & Rio Nombre de Dios & 666296 & 1058502 & 7.3 & 0.64 \\
\hline 24 & Rio Cuango & 686100 & 1055100 & 2.35 & 6.27 \\
\hline 25 & Rio Pequini & 660976 & 1035763 & 1 & 1.14 \\
\hline 26 & Rio Piedras (tributary to Upper Rio Chagres) & 675710 & 1026445 & ND & 1.25 \\
\hline 27 & Rio Pacora & 688094 & 1003560 & 8.04 & 1.15 \\
\hline
\end{tabular}

Rivers here are some of the longest in Panama and watersheds in this region are large, ranging $166-1797 \mathrm{~km}^{2}$ in size. These rivers have their headwater reaches in the fully forested highest 
elevations of the Cordillera Central but overall are characterized by $31-81 \%$ forest cover as a consequence of deforestation in their lower reaches.

Group 4 (Azuero Peninsula): Rivers of Azuero Peninsula of south-central Panama (Rio Escota, Rio Parita, and Rio La Villa) that drain a geologically complex upland terrain consisting of LateCretaceous-Early Tertiary intrusive and volcanic rocks that underlie the mid-Tertiary sediments to the nearby Pacific Ocean. These watersheds vary from $24-919 \mathrm{~km}^{2}$ in size and have a forest cover varying only $3-38 \%$.

Group 5 (El Valle Region): Rivers of the El Valle region of west-central Panama (Rio Anton, Rio Hato, and Rio Las Lajas) are largely formed on the silicic dacites and rhyolitic ignimbrites of the Late-Pleistocene age El Valle caldera volcanic complex (Defant et al., 1991) and run only short distances to the Gulf of Panama. Their watersheds vary only $12-435 \mathrm{~km}^{2}$ in size and have a diminished forest cover that varies $7-72 \%$.

Group 6 (Trans-Isthmus Region). This region of central Panama contains rivers (Rio Nombre de Dios, Rio Cuango, Rio Pequini, Rio Piedras, Rio Pacora) that largely drain the Chagres-Bayano Arc Complex that extends across the Chagres Uplands into east-central Panama. The geology of this area has been described by Wörner et al. (2005; 2009) and Wegner et al. (2011), with exposed igneous rocks here of ages between 65 to $45 \mathrm{Ma}$ for intrusive suites that range from gabbro and diorite to granodiorite and low-K granite. The Rio Pacora is formed on mafic igneous rock in its headwater region and flows across Tertiary marine sediments in its lower downstream reaches (Harmon et al., 2009) These watersheds vary from $12-414 \mathrm{~km}^{2}$ in size and have forest covers that vary 38-99\%. This region contains the two most pristine rivers in our study, the Rio Pequini and Rio Piedras, both largely-forested tributaries of the Upper Rio Chagres that have their headwaters in pristine triple canopy tropical rainforest. As noted by Condit et al. (2000), the forest of the Upper Rio Chagres drainage has been preserved as the Chagres National Park and therefore is largely undisturbed compared to most other areas of the Pacific slope of the Cordillera Central where forests have been largely cleared except in the highest, headwater areas. The Rio Nombre de Dios, Rio Cuango, and Rio Pacora also originate in this same headwater area but land uses in their lower reaches include various types of agriculture and suburban to urban impacts, with the Rio Pacora most significantly modified.

In general, the sedimentary rock-dominated landscapes of the Burica and Azuero peninsulas (Fig. 1) receive less rainfall and are characterized by higher mean annual temperature than the other regions of this study. The rivers draining these regions generally have higher total dissolved solids than rivers developed on the igneous terrains of the other four regions sampled (Harmon et al., 2013). All river systems, with the exceptions noted above, are directly affected by anthropogenic activities, with farming, grazing, low-density urbanization, and residential land use widespread across the Pan American Highway region of Chiriqui, Veraguas, Cocle, and 
Panama provinces where rivers were sampled. Truck farm agriculture, grazing, and urbanization form the prevailing land use in the northern headwater area of the Chiriqui province. Livestock grazing is the predominant land use in the semi-arid Azuero region and in the Burica Peninsula away from the urbanized coastal areas.

\section{Sampling and Analytical Procedures}

Water samples for DOC analysis were collected in one headwater stream of the Rio Chiriqui Viejo in the Volcán Barú area of western Panama and from the middle or lower reaches of 27 rivers across western and central Panama (Fig. 1; Table 1). This DOC study was undertaken as part of a larger, more comprehensive examination of the geochemistry of streams and rivers in west-central Panama (Harmon et al., 2013). Except in the Burica and Azuero peninsulas, all rivers sampled have their headwater reaches at the high elevation in the forested portion of the Cordillera Central and then flow either northwards in to Atlantic Ocean or southwards into the Pacific Ocean (Fig.1). The Rio Pequini and Upper Rio Chagres, which has the Rio Piedras as a major tributary, presently flow into the Lake Alajuela reservoir for Panama Canal operations.

Samples were collected by using the techniques outlined in Carey et al. (2005). Samples were collected at most locations during both the wet season (19-23 August 2006) and dry season (20 February to 1 March 2007). Samples were stored in the dark on ice immediately upon collection and shipped back to The Ohio State University within five days, where they were vacuum filtered directly into $20 \mathrm{ml}$ amber glass vials through Millipore ${ }^{\mathrm{TM}} 0.7 \mu \mathrm{m}$ nominal pore-size glass fiber filters. Filters, vials, and the filtration units had previously been combusted at $450{ }^{\circ} \mathrm{C}$ for 3 hours and later rinsed with $10 \%(\mathrm{v} / \mathrm{v}) \mathrm{HCl}$ in deionized water. After filtration, samples and blanks were acidified with $\mathrm{HCl}$ to $\mathrm{pH} 2$ and stored at $4{ }^{\circ} \mathrm{C}$. Analyses were performed using a Shimadzu 5050A Total Organic Carbon analyzer. The high sensitivity catalyst was used to quantify to $\sim 0.1 \mathrm{mg} \mathrm{l}^{-1}$ DOC. The normal sensitivity catalyst was used for concentrations in excess of $3.0 \mathrm{mg} \mathrm{l}^{-1}$ DOC. Samples were sparged with hydrocarbon-free air for up to 7 minutes prior to analysis to remove $\mathrm{CO}_{2}$. Each sample was injected 3-4 times. The relative standard deviation (RSD) of the multiple analyses of individual samples ranged $0.6-3.8 \%$. Filtration blanks and field blanks were also analyzed as samples. All blanks were below the limit of detection of $0.03 \mathrm{mg} \mathrm{l}^{-1}$ DOC. Accuracy of the measurement of the $1.0 \mathrm{mg} \mathrm{l}^{-1}$ concentration was $2.3-2.9 \%$.

In addition to the DOC samples, samples of the top $1 \mathrm{~cm}$ of surface streambed sediment were collected from mud deposits (sand-size grains and below) on the flood banks (13 samples in August 2006 and 2 in February 2007) using a nylon spoon. Samples were placed into clean, 
plastic ziplock bags and stored in the dark. After shipment back to Ohio State, samples were air dried and then analyzed for percent organic carbon using the dry combustion method and thermal conductivity detection with a Perkin-Elmer CHN2400 High Temperature Induction Furnace (Nelson \& Sommers, 1996) at the Ohio State University School of Environment and Natural Resources.

Estimates of the annual DOC yields were computed where stream discharge data were available. For the 2-year period covering our DOC measurements, the yields were determined using the mean daily discharge values for the wet and the dry seasons for 14 rivers with data provided by the Empresa Territorial para la Salud (ETESA). The Rio Pequini yields were calculated using discharge data from Harmon et al. (2009). Wet and dry seasonal discharge values were determined using the average monthly discharge values for the respective seasons. For both periods of record, the subsequent wet and dry seasonal yields were summed to determine the annual DOC yield. The ETESA discharge records range in length from 17 to 42 years in duration (mean $=41$ years) and are considered of high quality. As noted above, not all the rivers with samples analyzed for DOC had associated river discharge data and only 15 yields could be determined.

In an effort to place the data in context, we have provided average daily discharge values on the date of sample collection for 9 of the 13 rivers for which we calculated seasonal/annual DOC fluxes (Table 2; Fig. 2). Average daily discharge values for the day of sampling represent a decrease between $1 \%$ and $56 \%$ of their seasonal average values. This reduction in discharge is likely the result of 2006-07 being an El Niño period. Previous work has demonstrated clearly that during El Niño periods there is reduced rainfall and stream discharge in the Pacific slope areas of Central America (Waylen and Laporte, 1999). Furthermore, we observed an increase in wet season DOC concentrations for 24 out of 28 of our rivers. Others have identified increasing DOC concentrations and yields with increasing rainfall in tropical SMRs (Jeong et al., 2012; Lloret et al., 2013), particularly during intense precipitation events. Therefore, given the reduced discharge values at the time of sampling due to ENSO conditions, coupled with an expected increase in DOC concentrations with increased discharge, it is likely our yields are highly conservative. 
Table 2

Average daily and seasonal discharge values for select Panama rivers

\begin{tabular}{|c|c|c|c|c|c|c|c|c|}
\hline River & $\begin{array}{l}\text { Dry Season } \\
\text { Sample Date }\end{array}$ & $\begin{array}{l}\text { Daily } \\
\text { Dicherage }\end{array}$ & $\begin{array}{l}\text { Lumg- } \\
\text { Term Wet } \\
\text { can }\end{array}$ & $\begin{array}{l}\% \\
\text { difference }\end{array}$ & $\begin{array}{l}\text { Season } \\
\text { مamana }\end{array}$ & $\begin{array}{l}\text { Daily } \\
\text { Dicahorage }\end{array}$ & $\begin{array}{l}\text { Term Dry } \\
\text { Tana }\end{array}$ & $\begin{array}{l}\% \\
\text { difference }\end{array}$ \\
\hline \multicolumn{9}{|l|}{ Chiriqui Region } \\
\hline Rio Chiriqui Viejo & $8 / 20 / 2006$ & 70.9 & 80 & $-11 \%$ & $2 / 24 / 2007$ & 16.8 & 23.3 & $-28 \%$ \\
\hline Rio Chiriqui & $8 / 19 / 2006$ & 153 & 176 & $-13 \%$ & $2 / 24 / 2007$ & 29.4 & 47.7 & $-38 \%$ \\
\hline Rio Fonseca & $8 / 21 / 2006$ & 32.4 & 48.4 & $-33 \%$ & $2 / 24 / 2007$ & N/A & 16.9 & \\
\hline Rio San Juan & $8 / 21 / 2006$ & N/A & 18.0 & & $2 / 24 / 2007$ & 0.65 & 2.74 & $-76 \%$ \\
\hline Rio San Felix & $8 / 21 / 2006$ & 14.3 & 27.1 & $-47 \%$ & $2 / 24 / 2007$ & 1.34 & 3.05 & $-56 \%$ \\
\hline \multicolumn{9}{|l|}{ Veraguas-CocleRegion } \\
\hline Rio Santa Maria & $8 / 19 / 2006$ & 103 & 104 & $-1 \%$ & $2 / 26 / 2007$ & 16.4 & 33.1 & $-50 \%$ \\
\hline Rio Chico at Nata (tributary to Rio Grande) & $8 / 19 / 2006$ & 19.9 & 22.1 & $-10 \%$ & $2 / 26 / 2007$ & 3.25 & 4.00 & $-19 \%$ \\
\hline Rio Grande & $8 / 19 / 2006$ & 19.2 & 23.3 & $-18 \%$ & $2 / 26 / 2007$ & 2.55 & 9.35 & $-73 \%$ \\
\hline \multicolumn{9}{|l|}{ Azuero Peninsula } \\
\hline Rio La Villa & $8 / 21 / 2006$ & 13.3 & 41.5 & $-68 \%$ & $2 / 22 / 2007$ & 4.90 & 7.50 & $-35 \%$ \\
\hline
\end{tabular}

${ }^{a}$ Long-term adischarge data from Empresa de Transmisión Eléctrica (ETESA)

${ }^{b}$ Data not available for the date of sampling 


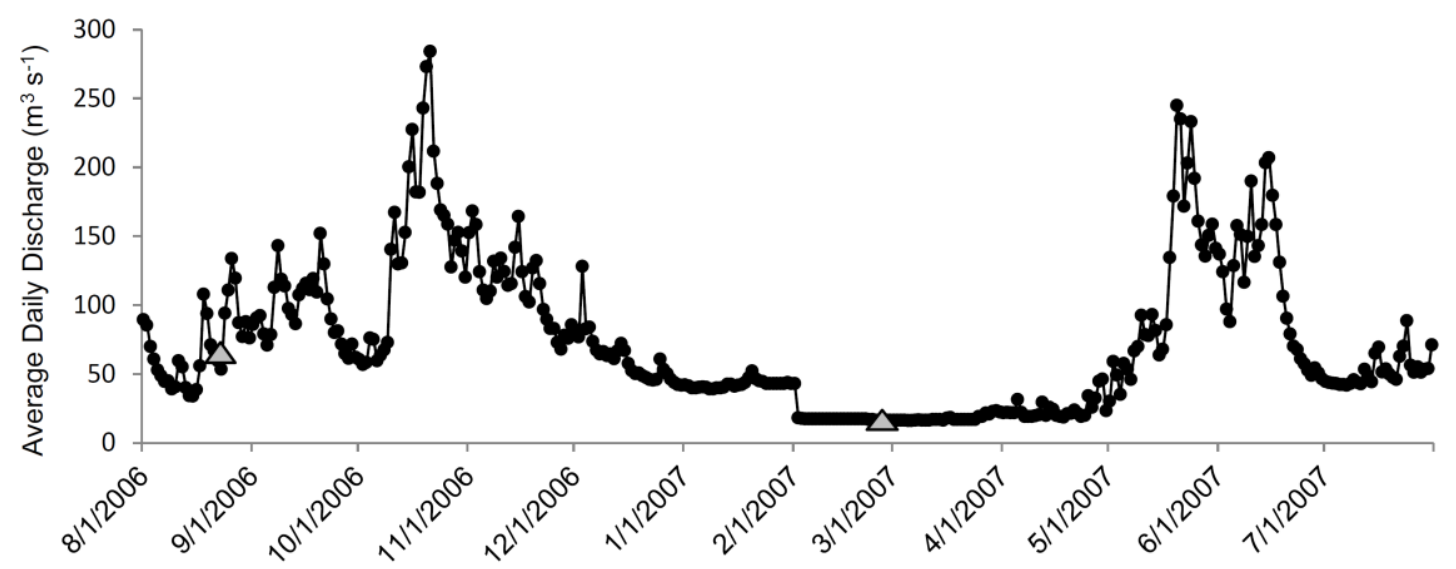

Figure 2. Average daily discharge values for the Rio Chiriqui Viejo for the 2006-2007 water year. Average daily discharge values for the day of sampling are denoted with triangles.

Finally, a digital elevation model (DEM) for the Panama watersheds was subsequently prepared to evaluate the control of landscape geomorphology, land cover and climate on DOC fluxes. The DEM is based on NASA Jet Propulsion Laboratory's Shuttle Radar Topography Mission (SRTM) 90m data (http://www2.jpl.nasa.gov/srtm/) and was generated using Global mapper (8.0 version). The DEM was used to determine watershed area and stream gradient for each of the watersheds. Land use cover was also incorporated into the DEM using data provided by the European Space Agency's Global Land Cover Map (http://due.esrin.esa.int/globcover/). Finally, average annual low/high temperature, annual minimum/maximum precipitation values were determined for each of the watersheds using data obtained from Esri's ArcAtlas (http://gcmd.nasa.gov/records/GCMD_ESRI_Arc_Atlas.html).

\section{Results and Discussion}

\subsection{The DOC and POC Dataset}

The DOC concentrations ranged $0.67 \mathrm{mg} \mathrm{l}^{-1}$ to $2.87 \mathrm{mg} \mathrm{l}^{-1}$ in the dry season and $0.76 \mathrm{mg} \mathrm{l}^{-1}$ to $>25 \mathrm{mg} \mathrm{l}^{-1}$ in the wet season (Table 1). Results of a two tailed t-test show $(\alpha=0.05)$ that the average wet season DOC concentration of all rivers is greater than in the dry $\left(t=2.54>t_{\text {crit }}=2.05\right.$; 
$\mathrm{p}=0.02$ ). Where samples for both the wet and dry seasons exist for an individual river, there are only three locations where the dry season concentrations are higher. These are Rio Santiago, Rio Pequini and Rio Cuango (Table 1). Recent work on other tropical mountainous watersheds has also demonstrated higher DOC concentrations during the wet portions of the year (Zhang et al., 2009) and higher DOC concentrations with higher discharges (Lloret et al., 2013). DOC values from this study are in line with those previously measured for the SMRs of Puerto Rico (1.32 to $2.16 \mathrm{mg} \mathrm{l}^{-1}$; McDowell and Asbury, 1994), Guadeloupe (0.52 to $7.22 \mathrm{mg} \mathrm{l}^{-1}$; Lloret et al., 2011) and New Zealand (1 to $7.6 \mathrm{mg} \mathrm{l}^{-1}$; Carey et al., 2005).

Spatial effects in DOC concentrations can be elucidated from the grouping the rivers into the geographic regions, as discussed above. For example, during the wet season, the Burica and Azuero Peninsula rivers and the Eastern Panama rivers have higher mean DOC concentrations than the Colon and Veraguas region rivers, which in turn have higher mean concentration than the El Valle and trans-Isthmus region rivers, which are higher than the mean values for Chiriqui region rivers (Table 1). The dry season regional means are much less variable, but the Azuero Peninsula rivers still have the highest means, followed by the Colon and Burica Peninsula region rivers, while the trans-Isthmus and Chiriqui region rivers have the lowest mean concentrations (Table 1). Groups 1 and 4 rivers (Burica and Azuera peninsula rivers) drain mid-Tertiary marine sedimentary rocks and sediments. These data suggest that land use and perhaps watershed lithology have some control on the DOC concentrations in these rivers.

It has been suggested that with respect to organic carbon transport, smaller headwater streams often have very different biogeochemical characteristics. These differences are thought to be due in part to differences in catchment geomorphology and ecology (Townsend-Small et al., 2005). This is particularly true of mountainous rivers, due to changes in terrestrial vegetation with respect to elevation (Townsend-Small et al., 2005).

The concentrations of DOC in the rivers of western-central Panama sampled in this study, for the most part, are similar to what has been observed in other tropical and mountainous regions. The exceptions are the very high wet season values observed in the marine sedimentary terrains of the Azuero and Burica Peninsulas (Table 1). A portion of the DOC in the sedimentary rockdominated watersheds could come from the weathering of the rocks themselves (Schillawski and Petsch, 2008) but currently there are no carbon characterization data (including ${ }^{14} \mathrm{C}$ ages) to confirm or disprove this idea. 
The sediment organic carbon concentrations range $0.2-5.2 \%$ and show no relationship to DOC concentration (Table 3). Furthermore, a relative lack of geographic distribution for the POC samples prevented a regional comparison.

Table 3

Paticulate organic carbon concentrations for 15 Panama rivers

\begin{tabular}{lccll}
\hline \multirow{2}{*}{ River } & $\begin{array}{c}\text { Sampling } \\
\text { UTM E }\end{array}$ & $\begin{array}{l}\text { Sampling } \\
\text { UTM N }\end{array}$ & Sample Date & \multirow{2}{*}{$\%$ OC } \\
\hline Group 6.Trans-Panama & Region & & & \\
Rio Piragua & 764201 & 1019310 & $2 / 22 / 2007$ & 0.85 \\
Rio Nombre De Dios & 666354 & 1058540 & $8 / 23 / 2006$ & 0.71 \\
Rio Diablo & 777830 & 1019110 & $8 / 23 / 2006$ & 0.19 \\
Rio Limpio & 670170 & 1029140 & $8 / 24 / 2006$ & 0.47 \\
Rio Pequini & 666327 & 1038560 & $8 / 23 / 2006$ & 0.55 \\
Rio Chepo & 787121 & 1017840 & $8 / 24 / 2006$ & 0.92 \\
Rio Piedras & 675721 & 1026460 & $8 / 24 / 2006$ & 0.57 \\
Rio Chico & 664040 & 1025010 & $8 / 24 / 2006$ & 5.23 \\
Rio Pacora & 689317 & 1006920 & $8 / 22 / 2006$ & 1.04 \\
Upper Rio Chagres & 689117 & 1035230 & $8 / 24 / 2006$ & 0.68 \\
Rio Cuango & 686168 & 1055140 & $8 / 23 / 2006$ & 0.84 \\
Rio Pacora & 689317 & 1006920 & $8 / 22 / 2006$ & 0.54 \\
Rio Esperanza & 680312 & 1036820 & $8 / 23 / 2006$ & 0.79 \\
Rio Espave & 755181 & 1024860 & $8 / 24 / 2006$ & 1.07 \\
Rio Carti Grande & 722329 & 1041960 & $2 / 22 / 2007$ & 1.88 \\
\hline
\end{tabular}

\subsection{DOC and POC yields and search for controlling variables}

With the annual runoff data where they exist, DOC yields have been calculated (Table $4 \&$ 5). The annual yields range $2.3-8.0$ tons $/ \mathrm{km}^{2} / \mathrm{y}$. The Azuero Peninsula rivers exhibited the highest average DOC yields $\left(7.2\right.$ tons $\left./ \mathrm{km}^{2} / \mathrm{y}\right)$ followed by those of the Chiriqui region (4.5 tons $/ \mathrm{km}^{2} / \mathrm{y}$ ). The Veraguas-Cocle and trans-Isthmus province rivers exhibited the next highest average DOC yields (3.7 and $3.5 \mathrm{tons} / \mathrm{km}^{2} / \mathrm{y}$, respectively) followed by those of the El Valle region (3.2 tons $\left./ \mathrm{km}^{2} / \mathrm{y}\right)$. The Panama DOC yields are equal to or lower than those from other tropical mountainous watersheds in Guadeloupe and Puerto Rico of 1.9-9.4 tons $/ \mathrm{km}^{2} / \mathrm{y}$ (Lloret et al., 2013; McDowell and Asbury, 1994; Stallard et al., 2012) and are equal to or slightly higher than those from mountainous rivers in New Zealand, Papua New Guinea, and Taiwan of 0.4-5.2 tons $/ \mathrm{km}^{2} / \mathrm{y}$ (Carey et al., 2005; Alin et al., 2008; Burns et al., 2008; Kao and Liu, 1997). However, our mean yield from these Panama rivers $\left(4.5\right.$ tons $\left./ \mathrm{km}^{2} / \mathrm{y}\right)$ is slightly lower than the 
mean determined previously for tropical river systems (6.0 tons $\left./ \mathrm{km}^{2} / \mathrm{y}\right)$ by Aitkenhead and McDowell (2000). It has also been demonstrated that, in general, DOC export from tropical rivers is not greater than from rivers and streams from other climatic types (McDowell and Asbury, 1994). In general, these yields from the Panama rivers are higher than yields from much larger rivers such as the Niger $\left(0.5\right.$ tons $\left./ \mathrm{km}^{2} / \mathrm{y}\right)$, Yukon $\left(1.5 \mathrm{tons} / \mathrm{km}^{2} / \mathrm{y}\right)$, St. Lawrence (1.35 ton tons $/ \mathrm{km}^{2} / \mathrm{y}$ ), and Mississippi (0.9 ton tons $/ \mathrm{km}^{2} / \mathrm{y}$ ) Rivers (Martin and Probst, 1991; Telang et al., 1991; Bianchi et al., 2004, respectively).

Table 4: Dissolved organic carbon yields from Panama Rivers

\begin{tabular}{|c|c|c|c|c|c|c|c|c|c|}
\hline \multirow{2}{*}{ River } & \multirow{2}{*}{$\begin{array}{l}\text { Watershed } \\
\text { Area } \\
\text { Upstream } \\
\text { of } \\
\text { Sampling } \\
\text { Site }\left(\mathrm{km}^{2}\right)\end{array}$} & \multirow{2}{*}{$\begin{array}{l}\text { Annual } \\
\text { Average } \\
\text { Discharge } \\
\left(\mathrm{m}^{3} / \mathrm{s}\right)^{\mathrm{a}}\end{array}$} & \multirow{2}{*}{$\begin{array}{l}\text { Wet } \\
\text { Season } \\
\text { Discharge } \\
\left(\mathrm{m}^{3} / \mathrm{s}\right)\end{array}$} & \multirow{2}{*}{$\begin{array}{l}\text { Dry } \\
\text { Season } \\
\text { Discharge } \\
\left(\mathrm{m}^{3} / \mathrm{s}\right)\end{array}$} & \multirow{2}{*}{$\begin{array}{l}\text { Years } \\
\text { of } \\
\text { Record }\end{array}$} & \multicolumn{3}{|c|}{ DOC Yields $\left(\mathrm{t} \mathrm{km}^{-2} \mathrm{yr}^{-1}\right)$} & \multirow[t]{2}{*}{$\begin{array}{l}\text { Geologic } \\
\text { Domain }\end{array}$} \\
\hline & & & & & & $\begin{array}{l}\text { Wet } \\
\text { Season }\end{array}$ & $\begin{array}{l}\text { Dry } \\
\text { Season }\end{array}$ & Annual & \\
\hline \multicolumn{10}{|l|}{ Chiriqui Region } \\
\hline Rio Chiriqui Viejo & 788 & 61 & 80.0 & 23.3 & 40 & 4.86 & 1.13 & 3.97 & QV \\
\hline $\begin{array}{l}\text { Rio Chiriqui Viejo } \\
\text { (headwater reach) }\end{array}$ & 108 & 6.43 & 7.17 & 5.19 & 39 & 12.96 & --- & --- & QV \\
\hline Rio Chiriqui & 1337 & 132 & 176 & 47.7 & 42 & 6.44 & 1.14 & 5.17 & QV \\
\hline Rio Fonseca & 406 & 36.4 & 48.4 & 16.9 & 21 & 7.18 & 1.23 & 5.75 & ARC \\
\hline Rio San Juan & 254 & 12.9 & 18.0 & 2.74 & 38 & 6.43 & 0.38 & 4.98 & $\mathrm{ARC}$ \\
\hline Rio San Felix & 198 & 19.2 & 27.1 & 3.05 & 14 & 3.28 & 0.33 & 2.57 & $\mathrm{ARC}$ \\
\hline \multicolumn{10}{|l|}{ Veraguas-Cocle Region } \\
\hline $\begin{array}{l}\text { Rio Santa Maria } \\
\text { Rio Chico at Nata } \\
\text { (tributary to Rio }\end{array}$ & 1370 & 80.6 & 104 & 33.1 & 42 & 8.19 & 0.90 & 6.44 & $\mathrm{ARC}$ \\
\hline Grande) & 316 & 15.9 & 22.1 & 4.00 & 41 & 4.39 & 0.42 & 3.43 & $\mathrm{ARC}$ \\
\hline $\begin{array}{l}\text { Rio Grande } \\
\text { Rio Cocle del Sur } \\
\text { (tributary to Rio }\end{array}$ & 471 & 18.1 & 23.3 & 9.35 & 41 & 3.13 & 1.15 & 2.66 & $\mathrm{ARC}$ \\
\hline Grande) & 310 & 6.92 & 9.78 & 1.39 & 28 & 2.95 & 0.20 & 2.29 & ARC \\
\hline \multicolumn{10}{|l|}{ Azuero Peninsula } \\
\hline Rio Parita & 451 & 10.9 & 16.2 & 1.25 & 23 & 10.42 & 0.20 & 7.97 & TS \\
\hline Rio La Villa & 1000 & 29.5 & 41.5 & 7.50 & 32 & 8.45 & 0.31 & 6.50 & TS \\
\hline \multicolumn{10}{|l|}{ El Valle Region } \\
\hline Rio Anton & 90 & 4.35 & 6.06 & 1.33 & 17 & 4.08 & 0.50 & 3.22 & QV \\
\hline \multicolumn{10}{|l|}{ Trans-Isthmus Region } \\
\hline $\begin{array}{l}\text { Rio Pequini } \\
\text { Rio Piedras (tributary to }\end{array}$ & 135 & 13.9 & 17.4 & 6.99 & 135 & 4.06 & 1.86 & 3.53 & ETT ARC \\
\hline Upper Rio Chagres) & 93 & 5.74 & & & 65 & --- & --- & --- & ETT ARC \\
\hline
\end{tabular}


Table 5: Comparison of Panama DOC to other high yielding locales

\begin{tabular}{ll}
\hline Geographic Region & $\begin{array}{l}\text { DOC Yields } \\
\left(\mathrm{t} \mathrm{km}^{-2} \mathrm{yr}^{-1}\right)\end{array}$ \\
\hline
\end{tabular}

\section{THIS STUDY}

Chiriqui Region

$2.57-5.75$

Veraguas-Cocle Region

$2.29-6.44$

Azuero Region

$6.50-7.97$

El Valle Region

Trans-Isthmus Region

3.53

\section{OTHER REGIONS}

$\begin{array}{ll}\text { Guadeloupe }^{\mathrm{a}} & 1.9-8.6 \\ \text { New Zealand }^{\mathrm{b}} & 0.6-5.2 \\ \text { Papua New Guinea }^{\mathrm{c}, \mathrm{d}} & 0.4-5.0 \\ \text { Puerto Rico }^{\mathrm{e}, \mathrm{f}} & 3.3-9.4 \\ \text { Taiwan }^{\mathrm{g}} & 4.1\end{array}$

Tropical river system mean value $^{\mathrm{h}}$ 6

${ }^{\mathrm{a}}$ Lloret et al. (2013), ${ }^{\mathrm{b}}$ Carey et al. (2005), ${ }^{\mathrm{c}}$ Alin et al. (2008), ${ }^{\mathrm{d}}$ Burns et al. (2008), ${ }^{\mathrm{e}} \mathrm{McD}$ Dowell and Asbury (1994), ${ }^{\mathrm{f}}$ Stallard (2012), ${ }^{\mathrm{g}} \mathrm{Kao}$ and Liu (1997), $\mathrm{h}, \ldots, 1,1 \times x$, 1 innnn

In an effort to evaluate potential controls on DOC yields in Panama, calculated values were compared to a variety of parameters including lithology (geologic domain), climate (annual low/high temperature, annual minimum/maximum precipitation), river geomorphologic character (minimum/maximum gradient, mean gradient, minimum/maximum elevation, mean elevation, watershed perimeter, channel length), land cover and extent (forest, agricultural, and grassland/shrubland), and previously determined long term physical erosion rates for Panama rivers from Sosa-Gonzalez (2011) (Table 6).

A comparison of DOC yields by lithological domain exhibited the following order: Tertiary Sediments $>>$ Quaternary Volcanics $\approx$ Volcanic Arc $>$ Early Tertiary Theolitic Island Arc. Results of a two tailed t-test $(\alpha=0.05)$ show that the average annual DOC yields for the TS terrain were significantly greater than that for the ARC terrain $\left(t=3.31>t_{\text {crit }}=3.18 ; p=0.05\right)$. A paucity of samples for the Early Tertiary Theolitic Island Arc terrain prevented a statistical comparison 
with that dataset. This finding was not unexpected as others have identified elevated yields in subtropical SMRs draining sedimentary and metamorphic regions of New Zealand and Taiwan (Carey et al., 2005; Kao and Liu, 1997), which possibly can be elevated due to a portion of the DOC originating from the weathering of the rocks themselves (Schillawski and Petsch, 2008). This idea is also supported by remote sensing obtained aboveground carbon density data for the Isthmus of Panama, which identified carbon stocks in the Chiriquí region (underlain by Quaternary volcanics) more than an order of magnitude greater than those for the Azuero Peninsula (underlain by Tertiary sediments) (Asner et al., 2013).

Table 6: Regression statistsics for Panama DOC Yields and select hydrogological, geomorphological and land cover paramaters

\begin{tabular}{|c|c|c|c|c|c|c|c|c|c|}
\hline & \multicolumn{3}{|c|}{ Annual DOC yield } & \multicolumn{3}{|c|}{ Dry season DOC yield } & \multicolumn{3}{|c|}{ Wet season DOC yield } \\
\hline & $\mathrm{n}$ & $r^{2}$ & $\mathrm{p}$ value & $\mathrm{n}$ & $r^{2}$ & $\mathrm{p}$ value & $\mathrm{n}$ & $\mathrm{r}^{2}$ & $\mathrm{p}$ value \\
\hline Runoff & 13 & $0.25^{*}$ & 0.42 & 13 & 0.58 & 0.04 & 13 & $0.21 *$ & 0.48 \\
\hline Physical Erosion Rates (m/myr) & 4 & $0.64 *$ & 0.36 & 4 & 0.12 & 0.88 & 4 & $0.30 *$ & 0.63 \\
\hline Landocver ( $\%$ forest $)$ & 13 & $0.35^{*}$ & 0.24 & 13 & 0.49 & 0.09 & 13 & $0.38 *$ & 0.20 \\
\hline Lancover (\% agricultural) & 13 & 0.26 & 0.40 & 13 & $0.50 *$ & 0.08 & 13 & 0.29 & 0.34 \\
\hline Landcover (\%grassland/shrubland) & 13 & 0.23 & 0.46 & 13 & $0.27 *$ & 0.38 & 13 & 0.24 & 0.42 \\
\hline Elevation Maximum (m) & 13 & $0.37 *$ & 0.21 & 13 & $0.01 *$ & 0.71 & 13 & $0.38 *$ & 0.21 \\
\hline Maximum Gradient & 13 & $0.57 *$ & 0.04 & 13 & $0.01 *$ & 0.97 & 13 & $0.56^{*}$ & 0.05 \\
\hline Mean Gradient & 13 & $0.55 *$ & 0.05 & 13 & $0.07 *$ & 0.82 & 13 & $0.54 *$ & 0.05 \\
\hline Annual Low Temperature $\left({ }^{\circ} \mathrm{C}\right)$ & 13 & $0.17 *$ & 0.58 & 13 & $0.19 *$ & 0.54 & 13 & 0.16 & 0.61 \\
\hline Annual High Temperature $\left({ }^{\circ} \mathrm{C}\right)$ & 13 & $0.17 *$ & 0.58 & 13 & $0.19 *$ & 0.54 & 13 & 0.16 & 0.61 \\
\hline $\begin{array}{l}\text { Annual minimum mean } \\
\text { Precipitation }(\mathrm{mm})\end{array}$ & 13 & $0.35 *$ & 0.24 & 13 & 0.52 & 0.07 & 13 & $0.39 *$ & 0.19 \\
\hline $\begin{array}{l}\text { Annual maximum mean } \\
\text { Precipitation }(\mathrm{mm})\end{array}$ & 13 & $0.35 *$ & 0.25 & 13 & 0.52 & 0.07 & 13 & $0.38 *$ & 0.20 \\
\hline
\end{tabular}


Previous work in tropical mountainous systems has demonstrated higher DOC concentrations or yields of DOC associated with land use type (Guyot and Wasson, 1994; Yang et al., 2013). However, no statistically significant relationship was observed between our annual DOC yields and percent forest area for the long term data set $(r=-0.35, \mathrm{p}=0.24)$ (Table 6). Interestingly, this relationship improved from negative to positive when considering dry season fluxes only ( $r=$ $0.49, \mathrm{p}=0.09$, respectively) suggesting percent of forest land cover may play a more active role in DOC export during baseflow conditions. This idea is supported by a statistically significant relationship between mean annual runoff with dry season DOC yields $(r=0.58, \mathrm{p}=0.04)$.

These relationships correspond with recent findings from the Aqua Salud experimental watersheds in Panama, suggesting that forest areas maintain relatively higher flow in these systems during the dry season (Ogden et al., 2013). Alternatively, this lack of a significant relationship may indicate that a general landuse category such as lumped forest types is not adequate to determine the importance of any one landscape component in influencing DOC flux.

Some previous work in tropical SMRs has demonstrated higher DOC concentrations or yields of DOC associated with elevation changes (Guyot and Wasson, 1994), whereas other research has not (Townsend-Small et al., 2005). Our analysis revealed statistically significant negative relationships were also observed between annual DOC yields and mean channel gradient $(r=0.55, \mathrm{p}=0.05)$ and maximum channel gradient $(r=0.57, \mathrm{p}=0.04)$. A previous study examining DOC yields from three tropical SMRs in Guadeloupe attributed relatively lower DOC yields in the Vieux-Habitants watershed to a relatively lower residence time of water in the system, as a result of its high overall percentage of steep slopes and highest mean annual rainfall in its headwater regions (Lloret et al., 2013). This influence of decreased residence time might explain our results that annual DOC yields $(r=-0.64, \mathrm{p}=0.36)$ are negatively, albeit statistically insignificantly, related to previously determined physical erosion rates of Sosa-Gonzalez (2011). Alternatively, relatively lower DOC concentrations observed at higher elevation from subtropical SMRs in Taiwan and southern China were attributed both to increased dilution from rainfall and to relatively lower population densities compared to their downstream counterparts (Yang et al., 2013). The majority of our samples were collected at the lower reaches of the watersheds and so we are unable to tease out relative anthropogenic impacts at different elevations within the same systems or within stream changes associated with elevation.

A comparison of annual DOC yields with climate parameters identified a negative correlation with minimum and maximum mean annual precipitation $(r=-0.35, \mathrm{p}=0.24)$. While this relationship held for both the annual and wet season values, the dry season values exhibited a positive correlation with these parameters $(r=0.52, \mathrm{p}=0.07)$. While much of Panama 
experiences distinct wet and dry seasons, precipitation across the Panamanian Isthmus is highly variable and convective rainfall is still generated year round in elevated areas of the Cordillera Central, which forms the headwaters for several streams in our study. While we cannot tease out the effects of headwater elevation on maintaining year round precipitation this varying relationship between seasonal DOC yields and minimum and maximum mean annual precipitation suggests a seasonal distribution of rainfall may minimize dilution effects.

Another important factor to consider is that 2006-07 was an El Niño period. Previous work has demonstrated clearly that during El Niño periods there is reduced rainfall and stream discharge in the Pacific slope areas of Central America (Waylen and Laporte, 1999). This suggests that our yields may be lower than what would be expected during average discharges due to ENSO conditions during our sampling period. No other statistically significant relationships were observed between DOC yields and any of the remaining parameters.

As observed in other SMRs (Guyot and Wasson, 1994, Jeong et al., 2012; Lloret et al., 2013), DOC yields can increase with specific discharge (Fig. 3). Karmalkar et al. (2008) have used the IPCC A2 scenario climate model for montane forests in Costa Rica and project an increase in temperature for this region, especially at higher elevations, and a decrease in precipitation of as much as $30 \%$. Their modeling also suggests a decrease in the frequency of high precipitation events with greater changes on the Pacific side. If this were also the case for the montane regions of Panama, one might expect that in the increased $\mathrm{CO}_{2}$ atmospheric environment of the future, DOC yields from these rivers might reflect this decreased discharge (assuming no major changes to present day land cover or land use patterns). Another important consequence of this decrease in discharge would be lower fluxes of total organic matter to the coastal zones. 


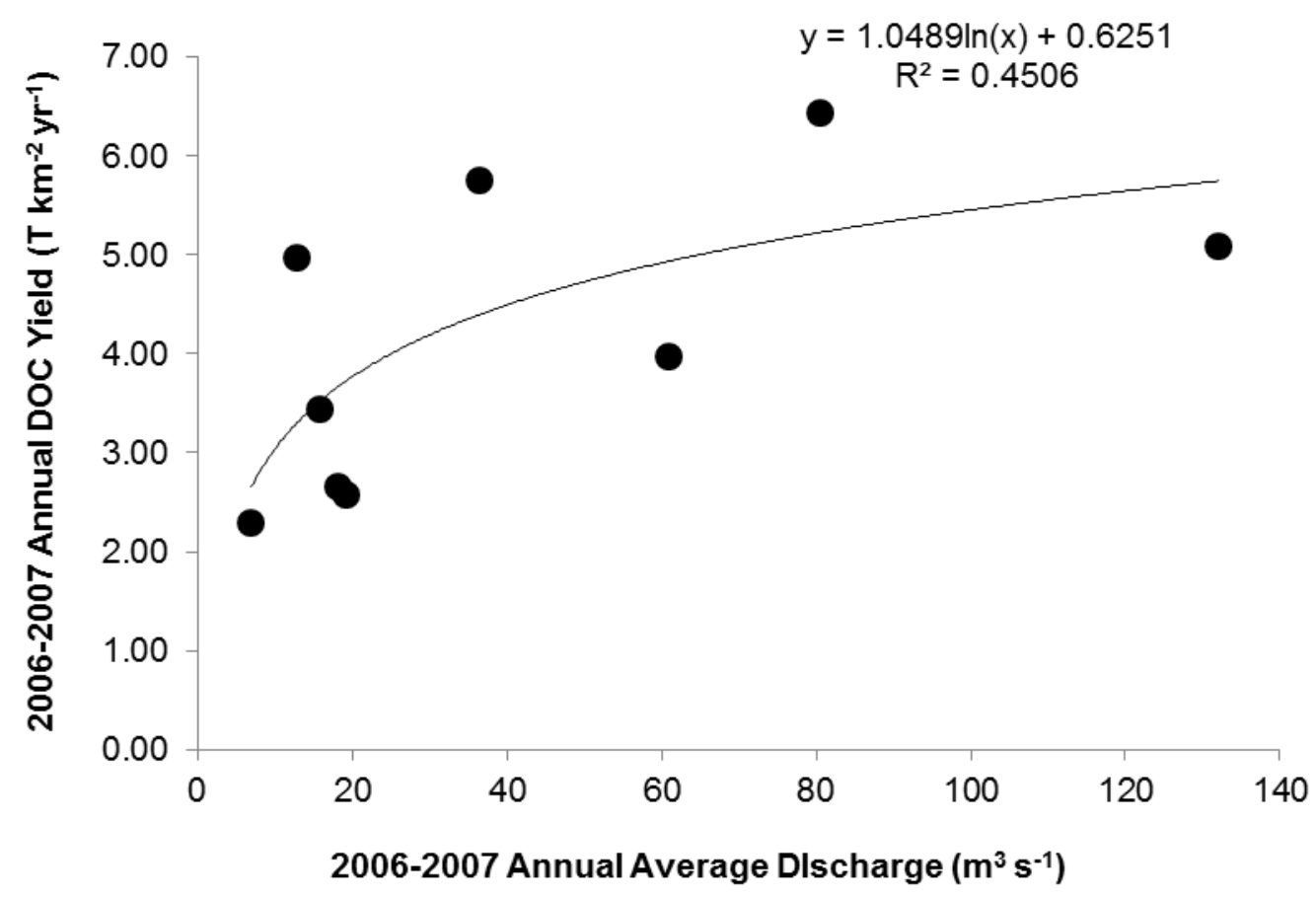

Figure 3. Dissolved organic carbon yield plotted versus river specific annual average discharge (excluding rivers from the Azuero Peninsula underlain by sedimentary lithology).

Long-term suspended load data exist only for the Rio Chagres (Nichols et al., 2005); so with those data and the Rio Pequini POC value, a POC yield of 1.9 tons $\mathrm{km}^{-2} \mathrm{a}^{-1}$, or $60 \%$ of the total (POC+DOC) yield was calculated for the Upper Chagres Basin. The Chagres POC yield is within the range of those previously determined for the small mountainous rivers draining of New Zealand (2.6-3.8 tons $\left.\mathrm{km}^{-2} \mathrm{a}^{-1}\right)$ by Carey et al. (2005). Surface $(0-8 \mathrm{~cm})$ soil organic carbon in the Upper Chagres Basin is $2.6-4.2 \%$ by weight (Hannah, 2009), suggesting that much of the organic matter produced in the forest is recycled in place on the landscape or during rapid transit through the aquatic system, as these soil OC concentrations are considerably higher than most of our stream POC values. Even though landslides mobilize large volumes of material in the Upper Chagres Basin, large woody debris in the Upper Rio Chagres watershed has a short residence time in the channels because of the flashy hydrographs with large peaks, and the resultant rapid transport times (Wohl et al., 2009). All these data and observations suggest that organic carbon is rapidly lost from the pristine, forested watersheds, either through rapid transport to the ocean or rapid decay and mineralization. 


\section{Conclusions}

DOC data have been presented for water samples collected during both the dry and the wet seasons for a selection of small to large rivers in Panama. Most of the headwaters of these rivers originate in high elevation regions of the country. DOC concentrations are higher in the wet season and DOC yields correlate strongly to the specific discharge in the watersheds. Both findings suggest that rainfall and runoff control the flux of DOC in these tropical environments. The POC concentrations are generally low, reflecting rapid transport and recycling of organic matter in these watersheds.

Yields of DOC are similar to or slightly lower than those determined from other tropical, SMR regions. Significantly higher mean DOC yields for regions underlain by Tertiary sediments compared to those underlain by igneous rocks suggests the important influence of lithology to DOC yields despite substantially lower aboveground carbon densities. Subsequent regression analyses between DOC yields and select watershed parameters revealed a negative and statistically significant relationship with mean elevation, maximum gradient and mean gradient suggesting lower soil retention times may be linked to lower DOC yields.

\section{Acknowledgements.}

This work was supported in part by funds to WBL from the College of Mathematical and Physical Sciences at The Ohio State University, and by an ARL Fellow stipend to RSH. We are grateful to personnel from the U.S. Army Proving Ground Tropical Regions Test Center, TRAXIAESA and Helipan Panama, Inc. for logistical support and sample collection activities and to S. A. Welch and K. A. Welch, Ohio State University for sample processing and analytical contributions.

\section{References Cited}

Alin, S.R., Aalto, R, Goñi, M.A., Richey, J.E., Dietrich, W.E., 2008. Biogeochemical characterization of carbon sources in the Strickland and Fly Rivers, Papua New Guinea. J. Geophys. Res., 113 F01505, doi:10.1029/2006/F000625.

Aitkenhead, J.A., McDowell, W.H., 2000. Soil C:N ratio as a predictor of annual riverine DOC flux at the local and global scales. Global Biogeochem Cycles. 14, 127-138.

Asner, G.P., Mascaro, J., Anderson, C., Knapp, D.E., Martin, R.E., Kennedy-Bowdoin, T., vanBreugel, M., Davies, S., Hall, J.S., Muller-Landau, H.C., Potvin, C., Souse, W., Wright, J., Bermingham, E., 2013. High-fidelity national carbon mapping for resource management and REDD+. Carbon Balance Man. 8, 1-14. 
Batjes, N.H., 1996. Total carbon and nitrogen in the soils of the world. Eur. J. Soil Sci. 47, 151163.

Bianchi, T.S., Filley T., Dria, K., Hatcher, P.G., 2004. Temporal variability in sources of dissolved organic carbon in the lower Mississippi River. Geochim Cosmochim. Acta. 68, 959-967.

Blair, N.E., Leithold, E.L., Ford, S.T., Peeler, K.A., Holmes, J.C., Perkey, D.W., 2003. The persistence of memory: The fate of ancient sedimentary organic carbon in a modern sedimentary system. Geochim. Cosmochim. Acta 67, 63-74.

Burns, K.A., Brunskill, G., Brinkman, D., Zagorskis, I., 2008. Organic carbon and nutrient fluxes to the coastal zone from the Sepik River outflow. Cont. Shelf Res. 28, 283-301, doi:10.1016/j.csr.2007.08.004.

Carey, A.E., Lyons, W.B., Gardner, C.B., Goldsmith, S.T., Hicks, D.M., 2005. Dissolved organic carbon yields from small mountainous rivers on New Zealand. Geophys. Res. Lett. 32(15): L15404, doi:10.1029/2005GL023159.

Cavelier, J., Solis, D., Jaramillo, M.A., 1996. Fog interception in montane forest across the central cordillera of Panama. J. Trop. Ecol. 12, 357-369.

Coates, A., Collins, L.S., Aubry, M.P., Berggren, W.A., 2004. The Geology of the Darien, Panama and the late Miocene-Pliocene collision of the Panama arc with northwestern South America. Geol. Soc. Am. Bull. 116, 1327-1344.

Coates, A.G. and Obando, J.A., 1996. Geologic evolution of the Central American Isthsmus: in Jackson, J.B.C., Bud, A.F., and Coates, A.G., eds., Evolution and Environment in Tropical America, University of Chicago Press, Chicago, p. 21-56.

Cole, J.J., Prairie, Y.T., Caraco, N.F., McDowell, W.H., Tranvik, L.J., Striegl, R.G., Kortelainen, P., Downing, J.A., Middelburg, J.J., Melack, J., 2007. Plumbing the global carbon cycles: Integrating inland waters into the terrestrial carbon budget. Ecosystems 10, 171-184.

Condit, R., Robinson, W.D., Ibanez, R., Aguilar, S., Sanjur, A., Martinez, R., Stallard, R.F., Garcia, T., Angehr, G.R., Petit, L., Wright, S.J., Robinson, T.R., Heckadon, S., 2001. The status of the Panama Canal watershed and its biodiversity at the beginning of the $21^{\text {st }}$ century. BioScience 51, 389-398.

Condit, R., Watts, K., Bohlman, S.A, Pérez, R., Hubbell, S.P., Foster, R.B., 2000. Quantifying the deciduousness of tropical forest canopies under varying climates. J. Veg. Sci. 11, 649658.

Defant, M.J., Clark, L.F., Stewart, R.H., Drummond, M.S., de Boer, J.Z., Maury, R.C., Bellon, H., Jackson, T.E., Restrepo, J. F., 1991. Andesite and dacite genesis via contrasting processes: The geology and geochemistry of El Valle Volcano, Panama. Contrib. Mineral. Petr. 106, 309-324.

Drummond, M.S., Bordelon, M., De Boer, J.Z., Defant, M.J., Bellon, H., Feigenson, M.D., 1995. Igneous petrogenesis and tectonic setting of plutonic and volcanic rocks of the Cordillera de Talamanca, Costa Rica-Panama, Central American arc. American Journal of Sci. 295, 875919. 
Escalante, G., 1990. The geology of southern Central America and western Colombia. In: Dengo, G., Case, J.E. (Eds.), The Geology of North America, Vol. H The Caribbean Region, Geological Society of America, Boulder, Colorado pp. 207-230.

Gao, Q., Tao, Z., Yao, G., Din, J., Liu, Z., Liu, K., 2007. Elemental and isotopic signatures of particulate organic carbon in the Zengjiang River, southern China. Hydrol. Processes 21, $1318-1327$.

Goldsmith, S.T., Carey, A.E., Lyons, W.B., Kao, S-.J., and Chen J., 2008. Geochemical fluxes from the ChoShui River during Typhoon Mindulle, July 2004, Geology, 36, 6 483-486.

Gomez, B., Trustrum, N.A., Hicks, D.M., Rogers, K.M., Page, M.J., Tate, K.R., 2003. Production, storage and output of particulate organic carbon. Waipaoa River basin, New Zealand. Water Resour. Res. 39, 1161, doi:10.1029/2002WR001619.

Guyot, J.L., Wasson, J.G., 1994. Regional pattern of riverine dissolved organic carbon in the Amazon drainage basin of Bolivia. Limnol. Oceanogr. 39, 452-458.

Hannah, L.M., 2009. A geochemical analysis of soils from the Rio Chagres Basin, Panama: Insight into regional chemical weathering processes and controls. Unpublished B.S. Honors thesis, School of Earth Sciences, The Ohio State University, Columbus, Ohio, USA. 33 pp.

Harmon, R.S., Lyons, W.B., Gardner, C.B., Goldsmith, S.T., Long, D.T., Mitasova, H., Welch, S., Welch, K., 2013, Surface Water Geochemistry and Chemical Weathering Across Panama: Proc. Earth Planet. Sci. 7, 342-345.

Harmon, R.S., Lyons, W.B., Long, D.T., Ogden, F.L., Mitasova, H., Gardner, C.B., Welch, K.A., Witherow, R.A., 2009. Geochemistry of four tropical montane watersheds, Central Panama. Appl. Geochem. 24, 624-640.

Hilton, R.G., Galy, A., Hovius, N., Chen, M.C., Horng, M.J., Chen, H., 2008. Tropical-cyclonedriven erosion of the terrestrial biosphere from mountains. Nature Geosci. 1, 759-762.

Hilton, R.G., Galy, A., Hovius, N., Kao, S.J., Horng, M.J., Chen, H., 2012. Climatic and geomorphic controls on the erosion of terrestrial biomass from subtropical mountain forest. Global Biogeochem Cycles. 26, doi:10.1029/2012GB004314.

Karmalkar, A.V., Bradley, R.S., Diaz, H.F., 2008. Climate change scenario for Costa Rican montane forests, 2008, Climate change scenario for Costa Rican montane forests. Geophys. Res. Lett. 35: L11702, doi:10.1029/2008GL033940.

Kao, S.J., Liu, K.K., 1997. Fluxes of dissolved and nonfossil particulate organic carbon from an Oceania small river (Lanyang Hsi) in Taiwan, (1996). Biogeochemistry 39, 255-269.

Komada, T., Druffel, E.R.M., Trumbore, S.E., 2004. Oceanic export of relict carbon by small mountainous rivers. Geophys. Res. Lett. 31: L07504, doi:10.1029/2004GL019512.

Kottek, M., Greiser, J., Beck, C., Rudolph, B., Rubel, F., 2006. World Map of Köppen-Geiger climate classification updated. Meteorol. Z. 15, 259-263.

Jeong, J.-J., Bartsch, S., Fleckenstein, J.H., Matzner, E., Tenhunen, J.D., Lee, S.D., Park, S.K., Park, J.-H, 2012. Differential storm responses of dissolved and particulate organic carbon in a mountainous headwater stream, investigated by high-frequency, in situ optical measurements. J. Geophys. Res. 117(G3), G03013, doi:10.1029/2012JG001999. 
Lachniet, M.S., Patterson, W.P., 2006. Use of correlation and stepwise regression to evaluate physical controls on the stable isotope values of Panamanian rain and surface waters. J. Hydrol. 324, 115-140.

Lloret, E., Dessert, C., Gaillardet, J., Albéric, P., Crispi, O., Chaduteau, C., Benedetti, M.F., 2011. Comparison of dissolved inorganic and organic carbon yields and fluxes in the watersheds of tropical volcanic islands, examples from Guadeloupe (French West Indies). Chem. Geol. 280, 65-78.

Lloret, E., Dessert, C., Pastor, L., Lajeunesse, E., Crispi, O., Gaillardet, J., Benedetti, M.F., 2013. Dynamic of particulate and dissolved organic carbon in small volcanic mountainous tropical watersheds. Chem. Geol. 351, 229-244, doi:10.1016/j.chemgeo.2013.05.023

Ludwig, W., Probst, J.-L., Kempe, S., 1996. Predicting the oceanic input of organic carbon by continental erosion. Global Biogeochem. Cycles 10, 23-41.

Lyons, W.B., Nezat, C.A., Carey, A.E., Hicks, D.M., 2002. Organic carbon flux from highstanding oceanic islands. Geology 30(5), 439-442.

Martin O, Probst J.-L., 1991. Biogeochemistry of major African rivers: Carbon and mineral transport. In: Degens, E.T., Kempe, S., Richey, J.E. (Eds.). Biogeochemistry of Major World Rivers, John Wiley, Hoboken, New Jersey, USA. pp.127-156.

McDowell, W.H., Asbury, C.E., 1994. Export of carbon, nitrogen, and major ions from three tropical montane watersheds. Limnol. Oceanogr. 39, 111-125.

Molnar, P., Sykes, L., 1969. Tectonics of the Caribbean and Middle American region from focal mechanisms and seismicity. Geol. Soc. Am. Bull. 80, 1639-1684.

Myers, N., Mittelmeier, R.A., Mittemeier, C.G., da Fonseca, G.A.B., Kent, J., 2000. Biodiversity hotspots for conservation priorities. Nature, 403, 853-858.

Nelson, D.W.,Sommers. L.E., 1996. Total carbon, organic carbon, and organic matter. In: D.L. Sparks, editor, Methods of Soil Analysis, Part 3. Chemical Methods. ASA-CSA-SSSA, Inc., Madison, WI. p. 961.

Nichols, K.K., Bierman, P.R., Finkel, R., Larsen, J., 2005. Long-term sediment generation rates for the Upper Chagres Basin. In: Harmon, R.S. (Ed.), The Rio Chagres, PanamaMultidisciplinary Profile of a Tropical Watershed, Springer, Dordrecht, Netherlands, pp. 297-313.

Ogden, F.L., Creel, J.N., Litt, G.F., 2013. Effect of land cover and use on dry season river runoff, runoff efficiency, and peak storm runoff in the seasonal tropics of Central Panama. Water Resour. Res. 49, 1-20, doi:10.1002/2013WR013956.

Peel, M.C., Finlayson, B.L., McMahon, T.A., 2007. Updated world map of the Köppen-Geiger climate classification. Hydrol. Earth Syst. Sci. 11, 1633-1644.

Rand, A.S., Rand, W.M., 1982. Variation in rainfall on Barro Colorado Island: in Leigh, E.G., Rand, S., and Windsor, D.M., eds., The Ecology of a Tropical Forest: Seasonal Rhythms and Long-Term Changes: Smithsonian Institution Press, Washington DC, p. 47-59.

Raymond, P.A., Bauer, J.E., 2001. Riverine export of aged terrestrial organic matter to the North Atlantic Ocean. Nature 409, 497-500. 
Schillawski, S, Petsch, S., 2008. Release of biodegradable dissolved organic matter from ancient sedimentary rocks. Global Biogeochem. Cycles 22, GB3002, doi: 10.1029/GB002980.

Sosa-Gonzales, V. 2011, Determining long term erosion rates in Panama- An application of ${ }^{10} \mathrm{Be}$ : University of Vermont, Masters Thesis, pp. 114p.

Stallard, R.F., 2012. Weathering, landscape equilibrium, and carbon in four watersheds in eastern Puerto Rico: Chapter H. In: Murphy, S.F., Stallard, R.F. (Eds.), Water quality and landscape processes of four watersheds in eastern Puerto Rico. U. S. Geological Survey, USGS Professional Paper 1789-H, Reston, Virginia, USA, pp. 199-248.

Stallard, R.F., 1985. River chemistry, geology, geomorphology, and soils in the Amazon and Orinoco basins: in Drever, J.I., ed, The Chemistry of Weathering, Reidel, Dordrecht, p. 293316.

Telang, S.A., Pocklington, R., Naidu, A.S., Romankevich, E.A., Gitelson, I.I., Gladysev, M.I., 1991. Carbon and mineral transport in major North American, Russian Arctic and Siberian Rivers: The Lawrence, Mackenzie, Yukon and Arctic Alaskan rivers. In: Degens, E.T., Kempe, S., Richey, J.E. (Eds.). Biogeochemistry of Major World Rivers, John Wiley, Hoboken, New Jersey, USA. pp.75-104.

Townsend-Small, A., McClain, M.E., Brandes, J.A., 2005. Contributions of carbon and nitrogen from the Andes Mountains to the Amazon River: Evidence from an elevational gradient of soils plants and river material. Limnol. Oceanogr. 50, 672-685.

Waylen, P., Laporte, M.S., 1999. Flooding and the El Niño-Southern Oscillation phenomenon along the Pacific coast of Costa Rica. Hydrol. Process. 13, 2623-2638.

Wegner, W., Wörner, G., Harmon, R.S., Jicha, B., 2011. Magmatic history and character of the Central American Land Bridge region since Cretaceous time. Geol. Soc. Am. Bull. 123, 703724.

Wohl, E., Ogden, F.L., Good, J., 2009. Episodic wood loading in a mountainous neotropical watershed. Geomorph. 111, 149-159.

Wohl, E., Barros, A., Brunsell, N., Chappell, N.A., Coe, M., Giambelluca, T., Goldsmith, S., Harmon, R., Hendrickx, J.M.H., Juvik, J., McDonnell, J., Ogden, F., 2012. The hydrology of the humid tropics. Nature Climate Change 2(9), 655-662, doi:10.1038/nclimate1556.

Wörner, G., Harmon, R.S., Hartmann, G., Simon, K., 2005. Igneous geology and geochemistry of the Upper Río Chagres Basin: in R.S. Harmon, ed., The Río Chagres, Panama: A Multidisciplinary Profile of a Tropical Watershed: Springer, The Netherlands, pp. 65-81.

Wörner, G., Harmon, R.S., Wegner, W., 2009. Geochemical evolution of igneous rock and changing magma sources during the formation and closure of the Central American land bridge of Panama: Backbone of the Americas: in Kay, S.M., Ramos, V.A., and Dickinson, V.A., eds., Shallow Subduction, Plateau Uplift, and Ridge and Terrane Collision.). Geol. Soc. Am. Mem. 204,183-196.

Yang, L., Hong, H., Chen, C.-T. A., Guo, W., Huang, T.-H., 2013. Chromophoric dissolved organic matter in the estuaries of populated and mountainous Taiwan. Mar. Chem. 157, 1223, doi:10.1016/j.marchem.2013.07.002. 
Zhang, S., Lux, X.X., Sun, H., Han, J., Diggitt, D.L., 2009. Geochemical characteristics and fluxes of organic carbon in a human-disturbed mountainous river (the Lodingjiang River) of the Zhujian (Pearl River). China. Sci. Total Environ. 407, 815-825. 